Meta

Journal des traducteurs

Translators' Journal

\title{
Still in search of a unit of translation: semantic situation
}

\section{Veronica Razumovskaya}

Volume 60, numéro 2, août 2015

$60^{\mathrm{e}}$ anniversaire. Les horizons de la traduction : retour vers le futur

$60^{\text {th }}$ Anniversary. Translation's Horizons: Back to the Future

60mo aniversario. Los horizontes de la traducción: regreso al futuro

URI : https://id.erudit.org/iderudit/1032918ar

DOI : https://doi.org/10.7202/1032918ar

Aller au sommaire du numéro

Éditeur(s)

Les Presses de l’Université de Montréal

ISSN

0026-0452 (imprimé)

1492-1421 (numérique)

Découvrir la revue

Citer ce document

Razumovskaya, V. (2015). Still in search of a unit of translation: semantic situation. Meta, 60(2), 367-367. https://doi.org/10.7202/1032918ar 


\title{
Still in search of a unit of translation: semantic situation
}

\author{
Veronica Razumovskaya \\ Siberian Federal University, Krasnoyarsk, Russia \\ veronica_raz@hotmail.com
}

The history of theory and practice of translation is inseparably connected with the definition of a unit of translation: its size and volume, structure and composition, nature and properties. The peculiarities and diversity of aesthetic and cultural information conveyed in an original literary text determine the inevitable variability of the types of units of translation. The possible size of a unit of translation can vary from the minimum size of a phoneme (phonosemantic level) up to the maximum size of a whole text (textual level). The present research deals with the semantic situation as a regular unit of literary translation. From the standpoint of semantic syntax, where the notion of a semantic situation originated, a semantic situation in belles-lettres texts is considered to be the language representation of an extralinguistic situation (real or fictional). A semantic situation undoubtedly implies a certain propositional content, possesses obligatory scenario nature, stores and generates cultural information and memory. Being represented in a literary text by a complex semantic model and revealing its cognitive image, a semantic situation is comprehensively constructed by the selection of the relevant predicates and actants. The ways of reconstruction the original semantic situations presented in the novel in verse "Eugene Onegin" (by the Russian classic writer A.S. Pushkin) in the secondary texts are studied. The following semantic situations were analyzed: wine drinking, fortune-telling, letter writing, dating, traveling. Particular attention is paid to the translation strategies dealing with cultural information and memory presented in Pushkin's text: foreignization, domestication and estranging. The newly coined category of estrangement has derived from the similar artistic technique and serves to be the vivid example of the translation paradigm expansion. The category of estrangement has developed into a key principle of art and generated the literary translation strategy of estranging, which is mostly orientated on the text elements carrying cultural information The broad and heterogeneous information space of the novel (characterized by a famous critic as an "encyclopedia of a Russian life") is the result of an accumulation of Russian and "other" cultural information. The numerous translations of the "strong" text of Russian culture into different foreign languages form one of the greatest centers of translation attraction.

Veronica Razumovskaya was awarded a Degree with Honours in English and German in 1980. Subsequently, she was a postgraduate student at Saint-Petersburg State University's Department of English, completing her PhD in Philology in 1985. She is the author of one monograph and three chapters in books (published in Poland, Turkey and the UK), and over 200 textbooks and articles dealing with various translation issues. She has supervised $6 \mathrm{PhD}$ theses in linguistics and translation studies. She is a member of the Union of Translators of Russia, MAPRAYL and ROPRYAL. She has taught at Kanazawa University (Japan), Durham University (the UK) and the Russian-Tajik Slavonic University (Tajikistan). Her most notable positions include Dean of the Department of Modern Foreign Languages, Head of the Chair of Translation Studies and Professor of the Chair of Business Communication at Siberian Federal University. 